\title{
血管狭窄部及び動脈瘤内血液拍動流における血液モデルの検討
}

\section{Investigation of Constitutive Models for Blood Flows in Blood Vessels with Stenosis and Aneurysm}

\author{
O正 撰 隆文 (高知工科大院) 正 辻 知宏 (高知工科大), 正 蝶野 成臣（高知工科大）
}

Takahumi ERAMI, Graduate School of Kochi University of Technology,Tosayamada-cho,Kochi,782-8502,Japan Tomohiro TSUJI, Kochi University of Technology, Tosayamada-cho,Kochi,782-8502,Japan Shigeomi CHONO, Kochi University of Technology, Tosayamada-cho,Kochi,782-8502,Japan

Key Words: Shear-Thinning, 3D-Blood Flow Analysis ,Pulsatile Flow, Wall Shear Stress

\section{1. 緒言}

血管内で起こる様々な疾患は複雑な形状を有した筒所に 多発する.そのため疾患の発生と血液流動に関連性があるこ とが示唆されているが，実際には未だ明らかにされていない のが現状である.血液の大きな特徴として非ニュートン性が あり，その特徵を現す代表的な血液モデルとして Casson モ デル, Carreau-Yasuda モデル, Bi-Viscosity ${ }^{(1)(2)}$ がある.

本研究は，上記モデルを用いて狭窄部及び動脈瘤を有する 血管内血液拍動流の有限要素解析を行う。得られた結果より, 各々のモデルについての特性の吟味及びモデルについての 比較検討を行う。解析領域は，狭窄部及び動脈瘤を有した管 とする.

\section{2. 基礎方程式}

連続の式，及び運動方程式は以下のように表される。 ・連続の式

$$
\nabla \cdot \mathbf{v}=0 \cdots \cdots \cdots \cdots \cdots \cdots \cdots \cdots \cdots \cdots
$$

- 運動方程式

$$
\rho D \mathbf{v} / D t=-\nabla p+\nabla \cdot \boldsymbol{\tau} \cdots \cdots \cdots \cdots \cdots \cdots
$$

ここでv は速度ベクトル， $\rho$ は密度， $D \mathrm{v} / D t$ は速度べクトルの実 質微分, $p$ は圧力, $\tau$ は偏差応力テンソルである. 本研究で用いた 血液モデルは Casson モデル, Bi-Viscosity モデルに修正を加えたモ デル, Carreau-Yasuda モデル，ニュートン流体の 4 種類であり，そ れぞれ以下のように表される.

・ 修正 Casson モデル

$$
\boldsymbol{\tau}=\left(S_{y} / \sqrt{2 I+\delta}+2 \sqrt{S_{y} \mu} / \sqrt[4]{2 I I+\delta}+\mu\right) \mathbf{A}
$$

・ 修正 Bi-Viscosity モデル

$$
\boldsymbol{\tau}=\left(S_{y} / \sqrt{2 I I+\delta}+\mu\right) \mathbf{A}
$$

- Carreau-Yasuda モデル

$$
\boldsymbol{\tau}=\left(\mu+\left(\mu_{0}-\mu\right) /\left(1+(\lambda I)^{b}\right)^{a}\right) \mathbf{A}
$$

ここで $S_{y}$ は降伏灾力, $\mu$ は無限せん断粘度, $\mu_{0}$ はゼ口せん断粘 度， $\delta$ は解析不可能点を解消寸る修正パラメータ，入は緩和時間, $\mathrm{a}, \mathrm{b}$ は任意の指数である. $\mathbf{A}$ は変形速度テンソル，II は変形速度 テンソルの第二不変量である

\section{3. 数值解析}

解析領域は直径 $D$, 長さ $15 D$ の円管であり，主流方向に $x$ 軸を 取る. 直径 $D$ の球形の狭窄部及び動脈瘤は, その中心が $x=5 D$ の 円管壁面上に位置しているものとする. 血液モデルのパラメータ, 血管径は実際の人間に近い值を用いた．拍動流の周期は $1 \mathrm{~s} と し ，$ 初期条件は流量波形中 $t=0 \mathrm{~s}$ における流量時の定常解とした。計算 は初期条件による周期性の問題を考慮し拍動 5 周期に渡って行っ
た (解析結果は十分な周期性が得られた $t=3.0 \mathrm{~s}$ からのものである.).

\section{4. 解析結果}

$x / D=5$ すなわち狭窄部頂点, 動脈瘤頂点における壁面せん 断応力の時間変化を図 1,2 亿示す. 領域自体が高せん断応 力領域である狭寉部頂点では, 各々のモデル間の違いはあま り顕著ではない。しかし全体的に Caason モデルと Carreou-Yasuda モデルのせん断応力值はニュートン流体と比 べて高い值を示している. 瘤頂点は, 流れの淀みにのため低 せん断応力領域であるため血液モデル間の違いが拍動流全 体に渡って顕著に表れている。

\section{引用文献}

(1) Leuprecht, A. and Perktold, K. , Computer Method in Biomechanics and Biomedical Engineering,4(2001),149-163.

(2) 石川拓司·Luis.F.R.GUIMARAES ·大島修造·山根隆一郎, 機論 B,62-600(1996-8),2957-2964.
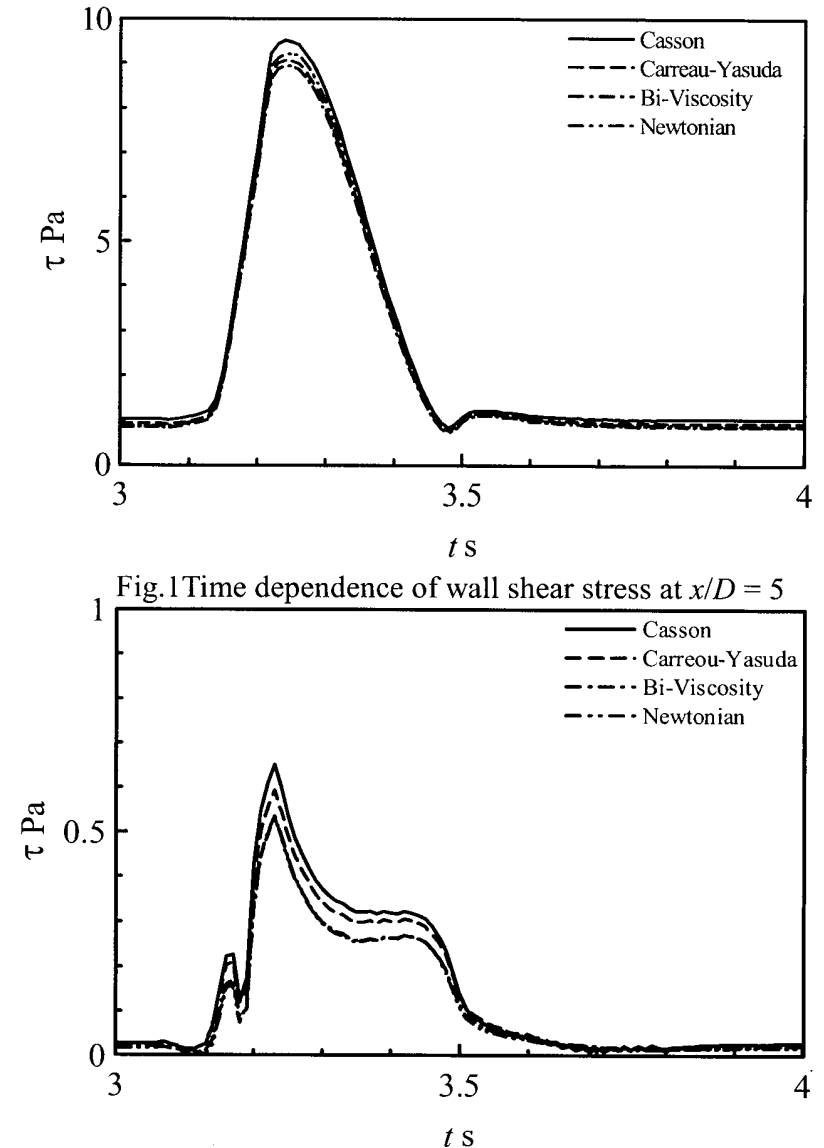

Fig.2 Time dependence of wall shear stress at $x / D=5$ 